\title{
Studies on physico-chemical properties of different vineyards in Bijapur Taluk, Karnataka
}

\author{
H. Yogeeshappa ${ }^{1}$, S. I. Tolanur ${ }^{1}$, R. N. Lakshmipathi' ${ }^{2}$, Mallikarjun ${ }^{1}$, \\ A. C. Mahendra ${ }^{1}$, Honnappa Asangi ${ }^{3 \star}$ and N. D. Yogendra ${ }^{1}$ \\ ${ }^{1}$ Department of Soil Science and Agricultural Chemistry, UAS, GKVK, Bangalore-560065, India. \\ ${ }^{2}$ Department of Agriculture Microbiology, UAS, GKVK, Bangalore-560065, India. \\ ${ }^{3}$ Department of PMAS, PG Centre, UHS(B), GKVK, Bangalore-560065, India.
}

Accepted 14 January, 2013

\begin{abstract}
Nutritional survey carried out in different grape growing regions of the country have revealed that the grape growers are applying as high as 600 to $800 \mathrm{~kg}$ each of $\mathrm{N}, \mathrm{P}_{2} \mathrm{O}_{5}$ and $\mathrm{K}_{2} \mathrm{O}$ per ha every year accounting for 30 to $40 \%$ of an annual occurring costs. Nutrients influence yield and quality of grapes through vine growth. A systematic investigation was conducted on soil fertility status of the low and high yielding vineyards in Bijapur taluk. Sixty vineyards were surveyed. Out of 60,30 vineyards were selected based on previous year yield data for the purpose of collecting soil and petiole samples. The vineyards which produced less than 10 tonnes per acre and those which produced more than 10 tonnes per acre were categorized as low yielding and high yielding vineyards, respectively. All the soils belong to clay in texture. The pH of soils was alkaline in reaction (8.19 to 8.50). The soils were non saline. The organic carbon content of the soils ranged from medium to high. The CEC of the soil ranged from 49.45 to 55.05 and 50.03 to $57.75 \mathrm{coml}$. $(p+) \mathrm{kg}^{-1}$. The available nitrogen content of the soils ranged from 161.90 to 212.21 and 193.50 to $233.47 \mathrm{~kg} \mathrm{ha}^{-1}$. The available phosphorus content in the soils ranged from 18.64 to 31.42 and 22.45 to $34.50 \mathrm{~kg} \mathrm{ha}^{-1}$. The available potassium content of the soil ranged from 432.64 to 472.81 and 430.64 to $543.39 \mathrm{~kg} \mathrm{ha}^{-1}$ in the low and high yielding vineyards, respectively.
\end{abstract}

Key words: Vineyards, nutrition, texture, alkaline.

\section{INTRODUCTION}

The popular grape varieties of South India are Anab-eShahi, Thompson Seedless, Gulabi and Bangalore Blue. These grape varieties are becoming increasingly popular in peninsular parts of India. In Karnataka, grape is commercially cultivated in northern parts of the state. Thompson Seedless, Tar-A-Ganesh, Sonaka and Arkavathi are important seedless cultivars of grape under cultivation in the state. Thompson seedless is gaining more popularity both as table purpose and raisin making because of its high total soluble solids, thin skin and desired shape. Commercial viticulture in India is hardly a few decades old and major grape growing states are Maharashtra, Karnataka, Tamil Nadu, Andhra Pradesh, Punjab and Haryana. Among all the grape growing states, Maharashtra occupies the largest area $(16,000$ ha) followed by Karnataka $(8,500$ ha). As far as productivity is concerned, Karnataka stands first followed by Maharashtra (Negi, 1999).

The fertility status of soil is of prime importance for the optimum use of land to increased crop production.

*Corresponding author. E-mail: Iux014@rediffmail.com. 
Table 1. Physical and chemical properties of soils of low yielding vineyards.

\begin{tabular}{|c|c|c|c|c|c|c|c|c|c|c|c|}
\hline \multirow{3}{*}{ Farmer's name (code) } & \multirow{2}{*}{\multicolumn{3}{|c|}{$\begin{array}{c}\text { Particle size distribution } \\
(\%)\end{array}$}} & \multirow{3}{*}{ Texture } & \multirow{3}{*}{$\mathrm{pH}(1: 2.5)$} & \multirow{3}{*}{$\begin{array}{c}E C \\
\left(\mathrm{dS} \mathrm{m}^{-1}\right)\end{array}$} & \multirow{3}{*}{$\begin{array}{l}\text { Organic carbon } \\
\qquad\left(\mathrm{g} \mathrm{kg}^{-1}\right)\end{array}$} & \multirow{3}{*}{ 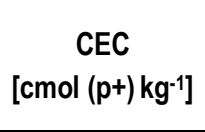 } & \multicolumn{3}{|c|}{ Available } \\
\hline & & & & & & & & & Nitrogen & Phosphorus & Potassium \\
\hline & Sand & Silt & Clay & & & & & & & $\left(\mathrm{kg} \mathrm{ha}^{-1}\right)$ & \\
\hline S. S. Patil (LYF1) & 10.17 & 22.61 & 65.41 & Clay & 8.35 & 0.26 & 6.8 & 53.67 & 196.82 & 28.47 & 465.72 \\
\hline B. S. Patil (LYF2) & 10.55 & 22.03 & 66.28 & Clay & 8.42 & 0.28 & 5.7 & 51.10 & 189.20 & 25.26 & 452.86 \\
\hline P. S. Kori (LYF $)$ & 11.16 & 20.63 & 66.72 & Clay & 8.46 & 0.29 & 6.3 & 51.11 & 182.43 & 22.92 & 446.20 \\
\hline S. H. Lagali $\left(\mathrm{LYF}_{4}\right)$ & 10.46 & 20.38 & 66.30 & Clay & 8.33 & 0.30 & 7.0 & 54.15 & 203.18 & 29.84 & 472.81 \\
\hline Mallappa Umbrani (LYF $\left.{ }_{5}\right)$ & 11.06 & 21.01 & 66.16 & Clay & 8.29 & 0.36 & 7.2 & 55.05 & 212.21 & 31.42 & 473.13 \\
\hline Sivanand Patil (LYF6) & 11.12 & 21.03 & 65.18 & Clay & 8.23 & 0.24 & 6.7 & 51.43 & 161.90 & 20.93 & 432.64 \\
\hline J. K. Matapathi (LYF $)$ & 11.12 & 21.13 & 66.07 & Clay & 8.40 & 0.29 & 6.5 & 52.69 & 196.72 & 27.82 & 463.46 \\
\hline Ashokgouda Biradar (LYF8) & 10.68 & 21.36 & 65.89 & Clay & 8.19 & 0.31 & 5.7 & 50.31 & 164.20 & 19.46 & 439.42 \\
\hline Horticulture Research Station $\left(\mathrm{LYF}_{9}\right)$ & 11.18 & 19.64 & 67.14 & Clay & 8.38 & 0.22 & 6.4 & 52.13 & 210.36 & 27.10 & 468.42 \\
\hline Suryakanth R. Biradar $\left(L^{\prime} F_{10}\right)$ & 10.37 & 21.48 & 66.46 & Clay & 8.32 & 0.25 & 6.2 & 49.45 & 172.81 & 18.64 & 470.12 \\
\hline Kalavathi C. Biradar $\left(\mathrm{LYF}_{11}\right)$ & 10.53 & 21.67 & 65.89 & Clay & 8.47 & 0.39 & 5.8 & 50.46 & 181.76 & 24.72 & 448.50 \\
\hline S. R. Biradar $\left(\mathrm{LYF}_{12}\right)$ & 10.47 & 22.16 & 66.76 & Clay & 8.43 & 0.38 & 7.1 & 51.85 & 202.10 & 28.72 & 460.72 \\
\hline Somaninga $\left(\mathrm{LYF}_{13}\right)$ & 11.29 & 21.17 & 66.18 & Clay & 8.38 & 0.31 & 6.9 & 50.56 & 194.62 & 26.80 & 452.62 \\
\hline Mallikarjuna Shilavantha (LYF 14$)$ & 10.49 & 20.12 & 66.70 & Clay & 8.44 & 0.37 & 6.6 & 54.01 & 203.46 & 29.20 & 463.17 \\
\hline Shivappa Godekar $\left(\mathrm{LYF}_{15}\right)$ & 11.08 & 21.04 & 66.43 & Clay & 8.29 & 0.30 & 6.4 & 50.67 & 192.87 & 23.82 & 450.62 \\
\hline Mean & 10.78 & 21.16 & 66.24 & & 8.36 & 0.30 & 6.5 & 51.91 & 190.98 & 25.67 & 457.36 \\
\hline
\end{tabular}

Information about the present status of soil fertility is of vital importance. Grape cultivation has assumed great significance in semi-arid region of Karnataka. Now, there is an increasing area under grape cultivation in Bijapur district. It has been experiencing decline in grape production also. Studies in the country have shown that the problem is mainly related to nutrient imbalance.

\section{MATERIALS AND METHODS}

Bijapur taluk is situated in the Northern Dry Zone (Region I and Zone-3) of Karnataka at $15^{\circ} 49^{\prime} \mathrm{N}$ latitude, $75^{\circ} 43^{\prime} \mathrm{E}$ longitude and altitude of $573 \mathrm{~m}$ above the mean sea level. The composite soil samples from the low and high yielding vineyards of Bijapur taluk were collected from a depth of 0 to $30 \mathrm{~cm}$ during summer season of 2006 before application of nutrients. The soils of the investigation site were shallow black, having alkaline $\mathrm{pH}$ and belongs to the Vertisol. Composite soil samples from a depth of 0 to $30 \mathrm{~cm}$ were collected in the low and high yielding vineyards before application of nutrients. Soil samples were also collected after October pruning for analysis.

Particle size analysis of the soil sample was carried out by International Pipette method using sodium hexametaphoshate as the dispersing agent as described by Piper (1966). Soil pH was determined in 1:2.5 soil:water suspension using $\mathrm{pH}$ meter with glass electrode as described by Jackson (1967). Electrical conductivity was determined in the supernatant solution of 1:2.5 soil:water suspension using digital conductivity bridge (Jackson, 1967). The organic carbon content was determined by Walkley and Black wet oxidation method (Jackson, 1967). The cation exchange capacity (CEC) of soil was determined by leaching the soil with neutral normal sodium acetate after removing the excess salts using 95 percent ethanol. The adsorbed sodium was replaced by neutral normal $\mathrm{NH}_{4} \mathrm{OAc}$ and the concentration of sodium in the leachate was determined by flame photometer (Black, 1965).

Available $\mathrm{N}$ of soil was determined by alkaline potassium permanganate distillation method as described by Subbiah and Asija (1956). Available P content of the soil was determined by Olsen's method as outlined by Jackson (1967). Available potassium was extracted with neutral normal ammonium acetate at $1: 5$ soil to extract ratio. The content of potassium in the extract was estimated by Flamephotometer (Jackson, 1967).

\section{RESULTS AND DISCUSSION}

The results on particle size analysis and chemical properties of soils in low and high yielding vineyards were the sand, silt and clay content in soils of low yielding vineyards ranged from 10.17 
Table 2. Physical and chemical properties of soils of high yielding vineyards.

\begin{tabular}{|c|c|c|c|c|c|c|c|c|c|c|c|}
\hline \multirow{3}{*}{ Farmer's name (code) } & \multirow{2}{*}{\multicolumn{3}{|c|}{$\begin{array}{c}\text { Particle size distribution } \\
(\%)\end{array}$}} & \multirow{3}{*}{ Texture } & \multirow{3}{*}{$\mathrm{pH}(1: 2.5)$} & \multirow{3}{*}{$\begin{array}{c}E C \\
\left(\mathrm{dS} \mathrm{m}^{-1}\right)\end{array}$} & \multirow{3}{*}{$\begin{array}{l}\text { Organic carbon } \\
\qquad\left(\mathrm{g} \mathrm{kg}^{-1}\right)\end{array}$} & \multirow{3}{*}{$\begin{array}{c}\text { CEC } \\
{\left[\mathrm{cmol}(\mathrm{p}+) \mathrm{kg}^{-1}\right]}\end{array}$} & \multicolumn{3}{|c|}{ Available } \\
\hline & & & & & & & & & \multirow{2}{*}{$\frac{\text { Nitrogen }}{\left(\text { kg ha-1) }^{-1}\right.}$} & \multirow[t]{2}{*}{ Phosphorus } & \multirow[t]{2}{*}{ Potassium } \\
\hline & Sand & Silt & Clay & & & & & & & & \\
\hline S. S. Gigini $\left(\mathrm{HYF}_{1}\right)$ & 10.55 & 22.12 & 66.26 & Clay & 8.47 & 0.14 & 7.1 & 52.25 & 215.94 & 32.20 & 522.81 \\
\hline Mallappa Umbrani ( $\left.\mathrm{HYF}_{2}\right)$ & 9.57 & 22.61 & 66.73 & Clay & 8.38 & 0.27 & 6.6 & 53.04 & 208.67 & 29.56 & 510.42 \\
\hline Rajashekhar S. Patil $\left(\mathrm{HYF}_{3}\right)$ & 10.13 & 21.92 & 66.06 & Clay & 8.45 & 0.26 & 6.7 & 52.89 & 205.82 & 25.43 & 508.86 \\
\hline Ganesh N. Nellandagi (HYF4) & 10.55 & 20.83 & 66.81 & Clay & 8.46 & 0.26 & 7.4 & 52.96 & 228.31 & 33.86 & 543.39 \\
\hline Shettappa S. Kichadi $\left(\mathrm{HYF}_{5}\right)$ & 11.04 & 21.54 & 65.91 & Clay & 8.27 & 0.27 & 6.8 & 57.75 & 202.43 & 27.84 & 483.21 \\
\hline S. S. Kichadi $\left(\mathrm{HYF}_{6}\right)$ & 10.51 & 21.16 & 66.24 & Clay & 8.41 & 0.16 & 7.0 & 50.96 & 204.14 & 28.12 & 487.03 \\
\hline Shivanand Holasanga $\left(\mathrm{HYF}_{7}\right)$ & 10.67 & 21.39 & 66.34 & Clay & 8.43 & 0.17 & 7.3 & 54.08 & 218.76 & 32.31 & 536.81 \\
\hline Bhumray M. Ittanghal (HYF8) & 11.01 & 20.64 & 65.86 & Clay & 8.32 & 0.17 & 6.7 & 55.90 & 193.50 & 22.45 & 430.64 \\
\hline S. J. Biradar $\left(\mathrm{HYF}_{9}\right)$ & 11.06 & 21.07 & 66.23 & Clay & 8.29 & 0.14 & 7.2 & 50.55 & 210.12 & 31.81 & 515.86 \\
\hline Sivanand N. Biradar (HYF 10$)$ & 10.86 & 20.95 & 67.14 & Clay & 8.47 & 0.25 & 7.5 & 56.01 & 233.47 & 34.50 & 479.12 \\
\hline V. R. Biradar $\left(\mathrm{HYF}_{11}\right)$ & 10.43 & 21.58 & 66.63 & Clay & 8.31 & 0.28 & 6.9 & 50.03 & 197.26 & 23.61 & 445.85 \\
\hline Mahadev Gondali $\left(\mathrm{HYF}_{12}\right)$ & 11.16 & 20.43 & 66.54 & Clay & 8.28 & 0.15 & 6.9 & 50.57 & 204.63 & 27.92 & 486.74 \\
\hline Revanasidda Belvundigi (HYF 13 ) & 11.08 & 22.09 & 65.12 & Clay & 8.29 & 0.21 & 6.8 & 50.94 & 201.87 & 26.74 & 497.63 \\
\hline Vijay Patil $\left(\mathrm{HYF}_{14}\right)$ & 11.32 & 21.21 & 65.51 & Clay & 8.28 & 0.22 & 7.1 & 51.60 & 208.25 & 29.23 & 506.90 \\
\hline Prakash Murigappa $\left(\mathrm{HYF}_{15}\right)$ & 9.83 & 21.65 & 66.72 & Clay & 8.39 & 0.18 & 6.7 & 53.44 & 212.47 & 31.18 & 518.42 \\
\hline Mean & 10.65 & 21.41 & 66.27 & & 8.37 & 0.21 & 7.0 & 52.86 & 209.71 & 29.12 & 498.25 \\
\hline
\end{tabular}

to $11.29,19.64$ to 22.61 and 65.41 to $67.14 \%$, respectively with mean values of $10.78,21.16$ and66.24\%, respectively (Table 1 ). In high yielding vineyards sand, silt and clay distribution ranged from 9.57 to $11.32,20.43$ to 22.61 and 65.12 to $67.14 \%$, respectively with mean values of $10.65,21.41$ and $66.27 \%$, respectively (Table 2 ). The low and high yielding vineyard soils were clay in texture. The perusal of data on mechanical analysis indicated that all the soil bodies studied were clay in texture. The clay content was more than $60 \%$ in all the soils. Govindarajan et al. (1979) also observed clay texture of black soils in Madurai Agricultural College Farm.

The $\mathrm{pH}$ of soil ranged from 8.19 to 8.47 with a mean of 8.36 at in initial soil samples of the low yielding vineyards (Table 1 ). The soil $\mathrm{pH}$ ranged from 8.20 to 8.41 with a mean of 8.32 at October pruning (Table 3 ). Soils were in alkaline in reaction. Under high yielding vineyards, the soil $\mathrm{pH}$ ranged from 8.27 to 8.47 with a mean of 8.37 in initial soil sample (Table 2), whereas, at October pruning, the soil pH ranged from 8.25 to 8.41 with a mean of 8.33 (Table 3 ). Soils were in alkaline in reaction. A perusal of the data on soil $\mathrm{pH}$ of the study area revealed that $\mathrm{pH}$ values varied from 8.2 to 8.5 . The soils are classified as slightly to moderately alkaline. Bhargava and Raghupathi (2001) observed soil $\mathrm{pH}$ in the range of 6.06 to 8.57. The organic carbon content in the soils of low yielding vineyards ranged from 5.70 to $7.20 \mathrm{~g}$ $\mathrm{kg}^{-1}$ with a mean value of $6.50 \mathrm{~g} \mathrm{~kg}^{-1}$ in an initial soil samples (Table 1) and it was varied from 5.80 to $7.20 \mathrm{~g} \mathrm{~kg}^{-1}$ with a mean of $6.60 \mathrm{~g} \mathrm{~kg}^{-1}$ at the time of October pruning (Table 3). The organic carbon content in the soils of high yielding vineyards ranged from 6.60 to $7.50 \mathrm{~g} \mathrm{~kg}^{-1}$ with a mean value of $7.00 \mathrm{~g} \mathrm{~kg}^{-1}$ initially (Table 2). Whereas, after October pruning, the soil organic carbon content ranged from 6.70 to $7.50 \mathrm{~g} \mathrm{~kg}^{-1}$ with a mean of $7.00 \mathrm{~g} \mathrm{~kg}^{-1}$ (Table 3). Soils of the study area contained medium to high quantities of organic carbon. Higher organic carbon content is due to intensive agriculture. Decay of plant residue have added more organic carbon in irrigated soils and also cropping pattern followed. The CEC of the low yielding vineyard soils ranged from 49.45 to $55.05 \mathrm{cmol}(\mathrm{p}+) \mathrm{kg}^{-1}$ with an average of $51.91 \mathrm{cmol}(\mathrm{p}+) \mathrm{kg}^{-1}$ in initial soil samples (Table 1). Whereas, the CEC in the soils of high yielding vineyards ranged from 50.03 
Table 3. Chemical properties and available nutrient status of soils of low and high yielding vineyards after October pruning.

\begin{tabular}{|c|c|c|c|c|c|c|c|c|c|c|c|c|c|}
\hline \multirow{4}{*}{$\begin{array}{l}\text { Farmer's } \\
\text { code }\end{array}$} & \multirow{4}{*}{$\underset{(1: 2.5)}{\mathrm{pH}}$} & \multicolumn{5}{|c|}{ Low yielding vineyards } & \multicolumn{7}{|c|}{ High yielding vineyards } \\
\hline & & \multirow{3}{*}{$\begin{array}{c}E C \\
\left(\mathrm{dS} \mathrm{m}^{-1}\right)\end{array}$} & \multirow{3}{*}{$\begin{array}{l}\text { Organic } \\
\text { carbon } \\
\left(\mathrm{g} \mathrm{kg}^{-1}\right)\end{array}$} & \multicolumn{3}{|c|}{ Available } & \multirow{3}{*}{$\begin{array}{l}\text { Farmer's } \\
\text { code }\end{array}$} & \multirow{3}{*}{$\underset{(1: 2.5)}{\mathrm{pH}}$} & \multirow{3}{*}{$\begin{array}{c}E C \\
\left(\mathrm{dS} \mathrm{m}^{-1}\right)\end{array}$} & \multirow{3}{*}{$\begin{array}{l}\text { Organic } \\
\text { carbon } \\
\left(\mathrm{g} \mathrm{kg}^{-1}\right)\end{array}$} & \multicolumn{3}{|c|}{ Available } \\
\hline & & & & Nitrogen & Phosphorus & Potassium & & & & & Nitrogen & Phosphorus & Potassium \\
\hline & & & & \multicolumn{3}{|c|}{$\left(\mathrm{kg} \mathrm{ha}^{-1}\right)$} & & & & & \multicolumn{3}{|c|}{$\left(\right.$ kg ha-1) $\left.^{-1}\right)$} \\
\hline $\mathrm{LYF}_{1}$ & 8.32 & 0.27 & 6.9 & 199.32 & 30.03 & 45.28 & $\mathrm{HYF}_{1}$ & 8.41 & 0.21 & 7.2 & 219.36 & 33.06 & 533.63 \\
\hline $\mathrm{LYF}_{2}$ & 8.36 & 0.29 & 5.9 & 193.21 & 26.83 & 41.83 & $\mathrm{HYF}_{2}$ & 8.34 & 0.27 & 6.8 & 213.61 & 30.89 & 521.87 \\
\hline $\mathrm{LYF}_{3}$ & 8.41 & 0.29 & 6.3 & 185.31 & 24.31 & 41.16 & $\mathrm{HYF}_{3}$ & 8.40 & 0.26 & 6.8 & 209.43 & 27.16 & 518.93 \\
\hline $\mathrm{LYF}_{4}$ & 8.30 & 0.26 & 7.2 & 210.08 & 32.83 & 47.01 & $\mathrm{HYF}_{4}$ & 8.41 & 0.25 & 7.4 & 231.71 & 34.73 & 558.86 \\
\hline $\mathrm{LYF}_{5}$ & 8.27 & 0.28 & 7.2 & 218.34 & 33.12 & 47.80 & $\mathrm{HYF}_{5}$ & 8.25 & 0.26 & 6.8 & 206.86 & 28.67 & 492.21 \\
\hline $\mathrm{LYF}_{6}$ & 8.22 & 0.24 & 6.8 & 167.14 & 22.33 & 40.23 & $\mathrm{HYF}_{6}$ & 8.38 & 0.19 & 6.9 & 208.63 & 29.73 & 495.41 \\
\hline $\mathrm{LYF}_{7}$ & 8.38 & 0.29 & 6.6 & 199.84 & 29.33 & 44.63 & $\mathrm{HYF}_{7}$ & 8.40 & 0.20 & 7.3 & 225.17 & 34.27 & 551.80 \\
\hline $\mathrm{LYF}_{8}$ & 8.20 & 0.30 & 5.8 & 167.42 & 20.96 & 36.81 & $\mathrm{HYF}_{8}$ & 8.29 & 0.19 & 6.7 & 197.36 & 24.23 & 438.73 \\
\hline $\mathrm{LYF}_{9}$ & 8.34 & 0.26 & 6.7 & 215.67 & 29.81 & 43.52 & $\mathrm{HYF}_{9}$ & 8.28 & 0.18 & 7.1 & 213.87 & 32.65 & 523.63 \\
\hline $\operatorname{LYF}_{10}$ & 8.29 & 0.29 & 6.3 & 175.12 & 19.13 & 35.21 & $H Y F_{10}$ & 8.39 & 0.26 & 7.5 & 236.45 & 35.89 & 592.47 \\
\hline $\mathrm{LYF}_{11}$ & 8.41 & 0.36 & 6.0 & 184.73 & 25.50 & 35.64 & $\mathrm{HYF}_{11}$ & 8.29 & 0.26 & 6.8 & 201.24 & 25.83 & 453.86 \\
\hline $\mathrm{LYF}_{12}$ & 8.39 & 0.32 & 7.1 & 207.81 & 30.22 & 43.48 & $\mathrm{HYF}_{12}$ & 8.26 & 0.19 & 6.8 & 207.64 & 29.76 & 494.42 \\
\hline $\mathrm{LYF}_{13}$ & 8.32 & 0.29 & 7.0 & 198.80 & 28.30 & 41.43 & $\mathrm{HYF}_{13}$ & 8.27 & 0.20 & 6.7 & 204.86 & 28.23 & 503.61 \\
\hline $\mathrm{LYF}_{14}$ & 8.37 & 0.31 & 6.8 & 206.84 & 30.70 & 44.76 & $\mathrm{HYF}_{14}$ & 8.26 & 0.21 & 7.0 & 212.26 & 30.73 & 515.83 \\
\hline $\mathrm{LYF}_{15}$ & 8.25 & 0.27 & 6.7 & 196.87 & 25.32 & 40.89 & $\mathrm{HYF}_{15}$ & 8.34 & 0.21 & 6.9 & 217.48 & 32.58 & 531.47 \\
\hline Mean & 8.32 & 0.29 & 6.6 & 195.10 & 27.25 & 41.98 & Mean & 8.33 & 0.22 & 7.0 & 213.73 & 30.56 & 515.12 \\
\hline
\end{tabular}

to $57.75 \mathrm{cmol}^{-1}(\mathrm{p}+) \mathrm{kg}^{-1}$ with an average of 52.86 $\mathrm{cmol}\left(\mathrm{p}+\mathrm{kg}^{-1}\right.$ in an initial soil samples (Table 2). In the soils of low and high yielding vineyards, higher CEC was observed. It might be due to higher clay content. Similar observations were made by Conradie and Saayman (1989).

The available nitrogen in soils of low yielding vineyards varied from 161.90 to $212.21 \mathrm{~kg}$ ha with an average of $190.98 \mathrm{~kg} \mathrm{ha}^{-1}$ in initial soil samples (Table 1). Whereas at the time of October pruning, the available $\mathrm{N}$ in the soil varied from 167.42 to $218.34 \mathrm{~kg} \mathrm{ha}^{-1}$ with an average of $195.10 \mathrm{~kg} \mathrm{ha}^{-1}$ (Table 3 ). In the soils of high yielding vineyards, the available $\mathrm{N}$ ranged from 193.50 to $233.47 \mathrm{~kg} \mathrm{ha}^{-1}$ with an average of $209.71 \mathrm{~kg} \mathrm{ha}^{-1}$ in initial soil samples (Table 2).
Whereas, at the time of October pruning, the available $\mathrm{N}$ in the soil ranged from 197.36 to $236.45 \mathrm{~kg} \mathrm{ha}^{-1}$ with an average value of $213.73 \mathrm{~kg}$ $\mathrm{ha}^{-1}$ (Table 3). Most of the soils of vineyards area of Bijapur taluk were low in available nitrogen content (Tables 1 to 3 ). This might be due to higher rate of mineralization due to high temperature (dry zone) and loss of nitrogen in the form of ammonia as the soils are calcareous. Similar observations were reported by Nitant and Dargan (1974).

The available phosphorus in the soils of low yielding vineyards ranged from 18.64 to $31.42 \mathrm{~kg}$ $\mathrm{ha}^{-1}$ with a mean value of $25.67 \mathrm{~kg} \mathrm{ha}^{-1}$ in initial soil samples (Table1) and at the time of October pruning, the available $P$ ranged from 19.13 to
$33.12 \mathrm{~kg} \mathrm{ha}^{-1}$ with a mean of $27.25 \mathrm{~kg} \mathrm{ha}^{-1}$ (Table 3 ). The available $P$ in the high yielding vineyards ranged from 22.45 to $33.86 \mathrm{~kg} \mathrm{ha}^{-1}$ with a mean $29.12 \mathrm{~kg} \mathrm{ha}^{-1}$ at an initial soil samples (Table 2), whereas at the time of October pruning, the available $P$ was ranged from 24.23 to $35.89 \mathrm{~kg} \mathrm{ha}$ ${ }^{1}$ with a mean of $30.56 \mathrm{~kg} \mathrm{ha}^{-1}$ (Table 3). The available phosphorus content in both the soils of the low and high yielding vineyards was in the range of low to medium (Tables 1 to 3 ). This might be due to the presence of excess $\mathrm{CaCO}_{3}$ and other soluble compounds of calcium. This present findings are in line with the results obtained by Ahlawat and Sindhu (1990) and Motsara (2002).

The available potassium in soils of low yielding vineyards, ranged from 432.64 to $473.13 \mathrm{~kg} \mathrm{ha}^{-1}$ 
with a mean value of $457.36 \mathrm{~kg} \mathrm{ha}^{-1}$ at an initial soil samples (Table 1) and 441.56 to $484.19 \mathrm{~kg} \mathrm{ha}^{-1}$ with a mean value of $466.05 \mathrm{~kg} \mathrm{ha}^{-1}$ at the time of October pruning (Table 3 ). The available $\mathrm{K}$ in the initial soils (Table 2) of high yielding vineyards ranged from 430.64 to $543.39 \mathrm{~kg} \mathrm{ha}^{-1}$ with an average of $498.25 \mathrm{~kg} \mathrm{ha}^{-1}$ and at the time of October pruning, the available potassium in soils varied from 438.73 to 592.47 with an average of $515.12 \mathrm{~kg} \mathrm{ha}^{-1}$ (Table 3).

\section{REFERENCES}

Ahlawat VP, Sindhu SS (1990), Nutritional survey of grape orchards of Haryana. Haryana J. Hort. Sci. 19(1-2):96-100.

Bhargava BS, Raghupathi HB (2001), Soil and plant diagnostic norms of perlette grape. Haryana J. Hort. Sci. 30(3-4):165-167.

Black CS (1965), Methods of Soil Analysis (Part 2); Agronomy Monograph 9, American Society of Agronomy, Medison, Wisconsin, USA. pp. 149-157.

Conradie WJ, Saayman D (1989), Effect of long-term nitrogen, phosphorus and potassium fertilization on Chenin Blanc vines. Am. J. Enol. Vitic. 40(2):85-90.

Govindarajan K, Venkataramana CR, Kandaswamy P, Raniperumal, Krishnamurthy P (1979). Classification of soils of Madurai Agricultural College Farm. Madras Agric. J. 66(8):756.
Jackson ML (1967). Soil Chemical Analysis, Prentice Hall of India Pvt. Ltd. New Delhi. P. 205.

Motsara MR (2002), Available nitrogen, phosphorus and potassium status of Indian soils as depicted by soil fertility maps. Fert. News. 47:15-21.

Negi JP (1999). Indian Horticulture Database. National Horticulture Board, Gurgaum, P. 37.

Nitant HC, Dargan KS (1974), Influence of nitrogenous fertilizers on yield and nitrogen uptake of wheat in saline sodic soils. J. Ind. Soc. Soil Sci. 22:121-124.

Subbiah BV, Asija, GL (1956). A rapid procedure for the estimation of available nitrogen in soils. Curr. Sci. 25:259-260. 